Opini

\title{
PEMBANGUNAN MASYARAKAT DALAM PERSPEKTIF PENYULUHAN
}

\section{Puji Hardiyanti}

\begin{abstract}
To succeed the national development to achieve its goal, the community participation plays a very strategic role. This article discusses a number of models, methods, and techniques how to motivate the communities as human resources to take part in the development. The models introduced and discussed include Laku and SL-PHT. The strength and the weakness of each model are described thoroughly considering andragogy and continuous learning are the principles in community development.
\end{abstract}

Keywords:

\section{PENDAHULUAN}

Sumber daya pembangunan terdiri dari sumber daya alam dan manusia. Dalam menyongsong era globalisasi, pembangunan sumber daya itu mempunyai peranan yang sangat penting, baik dalam pembangunan ekonomi maupun pembangunan nasional secara keseluruhan. Pembangunan pada hakekatnya adalah upaya mencapai taraf hidup manusia yang lebih berkualitas sesuai dengan nilainilai yang berlaku. Sekarang ini proses pembangunan telah sampai pada tahap yang mensyaratkan adanya partisipasi dari masyarakat yang lebih besar agar tujuan pembangunan dapat tercapai. Partisipasi masyarakat dalam pembangunan bukan hanya berarti pengerahan tenaga masyarakat secara sukarela, tetapi justru yang lebih penting adalah tergeraknya masyarakat untuk mau memanfaatkan kesempatankesempatan memperbaiki kualitas hidup sendiri. Apabila kesempatan-kesempatan itu tidak dimanfaatkan, maka kualitas hidup masyarakat tidak akan berubah dan tujuan pembangunan pun tidak tercapai.

Apakah masyarakat dengan sendirinya mau memanfaatkan kesempatan-kesempatan itu? Pengalaman empiris menunjukkan bahwa hal itu tidak akan terjadi dengan sendirinya. Masyarakat perlu mengalami suatu proses belajar untuk mampu mengetahui kesempatan-kesempatan untuk memperbaiki kehidupan. Setelah mengetahui, kemampuan atau ketrampilan mereka seringkali masih perlu ditingkatkan agar dapat memanfaatkan kesempatankesempatan itu. Setelah mengetahui dan memiliki kemampuan untuk memanfaatkan kesempatan, seringkali orang belum juga mau melakukannya. Oleh karena itu, seringkali diperlukan usaha khusus untuk membuat masyarakat mau bertindak memanfaatkan kesempatan memperbaiki kehidupan. Agar pembangunan dapat mencapai hasil yang baik, diperlukan usaha-usaha khusus yang bersistem dan berstrategi.

Semua yang dikemukakan di atas merupakan ruang lingkup tugas penyuluhan pembangunan, dan pengetahuan yang dapat digunakan untuk membuat tugas penyuluhan pembangunan menjadi lebih mudah adalah Ilmu Penyuluhan Pembangunan. Dengan demikian masalah yang perlu dikaji dan diperjelas ialah: (1) apakah yang dimaksud dengan penyuluhan pembangunan, (2) bagaimana penyuluhan itu dapat meningkatkan partisipasi masyarakat, (3) bagaimana pola-pola penyuluhan, dan (4) pola mana yang paling sesuai untuk meningkatkan partisipasi masyarakat? Tulisan ini mencoba membahas pertanyaan-pertanyaan tersebut dengan mengacu pada kajian teoritik dan pengalaman empiris.

\section{PEMBAHASAN}

\section{Apakah Ilmu Penyuluhan Pembangunan}

Ilmu Penyuluhan Pembangunan adalah suatu ilmu yang bersifat interdisipliner. Ilmu ini dapat digunakan sebagai alat rekayasa pembangunan nasional pembentuk pola perilaku masyarakat, baik perilaku aparat pembangunan dan pelaku penyuluhan (lembaga dan aparat penyuluhan) dalam menyajikan strategi penyuluhan alternatif maupun khalayak sasaran pembangunan. Ilmu penyuluhan pembangunan, pada awal kegiatannya, disebut dan dikenal sebagai Agricultural Extension (penyuluhan pertanian), terutama di beberapa negara seperti Amerika Serikat, Inggris, dan Belanda. Karena ilmu itu kemudian berkembang penggunaannya di bidangbidang lain maka berubah namanya menjadi Extension 
Education, dan di beberapa negara lain disebut Development Communication. Meskipun antara tiga istilah itu ada perbedaan, namun pada dasarnya semua mengacu pada disiplin ilmu yang sama. Di Indonesia, disiplin ilmu itu disebut Ilmu Penyuluhan Pembangunan sebagai pengembangan dari Ilmu Penyuluhan Pertanian.

Secara internal manusia cenderung mempertahankan pola perilaku yang telah dimiliki, serta mempertahankan kebiasaan-kebiasaan dan adat istiadat. Kalaupun manusia berubah dari zaman ke zaman, itupun terutama karena pengaruh lingkungan, baik pengaruh lingkungan alam, fisik maupun lingkungan sosial. Penyuluhan pembangunan berusaha mengendalikan atau memanipulasi lingkungan tersebut sedemikan rupa sehingga mampu mempengaruhi orang-orang tertentu untuk mau mengubah pola perilakunya yang akan memperbaiki mutu kehidupan mereka. Oleh karena itu Ilmu Penyuluhan Pembangunan adalah suatu disiplin ilmu yang mempelajari bagaimana pola perilaku manusia pembangunan terbentuk, bagaimana perilaku manusia dapat berubah atau diubah sehingga mau meninggalkan kebiasaan lama dan menggantinya dengan perilaku baru yang berakibat kualitas kehidupan orang yang bersangkutan menjadi lebih baik. Dalam implementasinya ilmu penyuluhan pembangunan memerlukan konsep-konsep ilmu yang lain seperti ilmu pendidikan, psikologi, antropologi, sosiologi, psikologi sosial, dan manajemen. Karena penyuluhan pembangunan selalu menitikberatkan pada perbaikan kualitas kehidupan manusia, lahir dan batin, maka kegiatan yang dilakukan pun selalu erat kaitannya dengan ilmu-ilmu lain.

Seperti pada pembangunan pertanian, yang melibatkan berjuta-juta petani, tidak mungkin berhasil bila hanya mengandalkan ilmu pertanian dalam arti monodisiplin.

\section{Penyuluhan Pembangunan dalam Meningkatkan Kepedulian Masyarakat}

Masyarakat akan timbul dan dapat dipacu untuk tumbuh dari kondisi sosial tertentu jika keyakinan akan manfaat suatu inovasi pembangunan dapat dirumuskan dan dipastikan. Untuk meningkatkan masyarakat terlibat aktif dalam pembangunan manusia seutuhnya maka penyuluhan pembangunan berfungsi dan berperan sebagai berikut.

1. Penerima gagasan, inspirasi dan aspirasi khalayak sasaran penyuluhan.

2. Motivator yang mampu mendorong khalayak sasaran penyuluhan untuk merasa bertanggung jawab dalam melaksanakan dan memelihara hasil-hasil pembangunan.
3. Pencari solusi masalah yang dihadapi oleh khalayak sasaran penyuluhan dengan memanfaatkan gagasan-gagasan dan potensi sumber daya yang tersedia di masyarakat.

Beragam strategi penyuluhan pembangunan akan berdampak positif apabila tujuan program pembangunan dapat tercapai dan perubahan perilaku khalayak sasaran penyuluhan sebagai tujuan akhir dapat diamati dan diukur. Hal ini dapat dilakukan dengan mendifusikan inovasi pembangunan ke dalam sistem sosial masyarakat. Kriteria keberhasilan beragam strategi inovasi pembangunan perlu dikaitkan denga kekhasan tiap inovasi pembangunan. Kriteria tersebut tidak hanya mengukur keberhasilan atau kegagalan khalayak sasaran penyuluhan dalam menerapkan inovasi pembangunan, tetapi juga kesuksesan dan ketidaksuksesan pelaku penyuluhan pembangunan dalam mengalihkan informasi pembangunan dalam keterpaduan. Kriteria keberhasilan penyuluhan pembangunan dari sudut khalayak sasaran penyuluhan dicirikan oleh hal-hal berikut. (1) Adanya unsur pemahaman, kepedulian, dan kemampuan masyarakat dalam menyeleksi dan menerapkan beragam inovasi pembangunan. (2) Komitmen dan kesepakatan aktif untuk meningkatkan kesuksesan beragam dimensi program pembangunan. (3) Kehidupan yang lebih baik. Bagi pelaku penyuluhan pembangunan untuk mencapai kriteria tersebut dengan memberikan citra positif di mata masyarakat dengan cara memberikan kemudahan pelayanan penyuluhan dan penyampaian informasi pembangunan yang lengkap dan benar berkenaan dengan prioritas utama pada kepentingan khalayak sasaran penyuluhan disamping itu melakukan perluasan jangkauan informasi, dan pemantapan kelembangaan masyarakat dengan memperhatikan aspek kebudayaan setempat.

\section{Pola-Pola Penyuluhan Pembangunan}

Penyuluhan pembangunan dilakukan secara sistematis, berencana dan diikuti dengan kejelasan dalam hal tujuan, sasaran dan materi penyuluhan serta metode dan teknik penyuluhan dengan berorientasi pada falsafah pendidikan orang dewasa. Seperti telah diuraikan terdahulu bahwa penyuluhan pembangunan berawal dari penyuluhan pertanian, maka dalam menerapkan metode pembangunan masyarakat lebih berorientasi pada masyarakat petani. Gambaran bentuk-bentuk kegiatan dalam penyuluhan pertanian yang telah dilaksanakan sebagai berikut.

\section{Model Kerja Laku}

Laku adalah akronim dari Latihan dan Kunjungan. Pencetus gagasan atau ide sistem Laku 
ini adalah Bennor dan Horisson yang dicoba pertama kali di Bangladesh pada tahun 1970-an. Model ini diterapkan agar terjalin hubungan yang akrab antara seorang penyuluh dengan para petani beserta keluarganya. Hubungan yang akrab ini ditumbuhkan dan dibina dengan sistem kerja yang tertib, teratur, dan berkesinambungan (kontinuitas). Selain itu bahan atau materi penyuluhan yang diberikan haruslah aktual, segar, dan diperlukan oleh para petani pada saat itu dan penyampaiannyapun harus di lapangan di tempat para petani melaksanakan usaha taninya. Oleh karena itu, bahan materi yang akan disampaikan harus terlebih dahulu dikuasai oleh seorang penyuluh dengan baik, dengan demikian dalam pemberian informasi dapat lebih jelas dan mengesankan para petani beserta keluarganya. Pengertian sistem kerja "Laku" adalah sebagai berikut.

a. Latihan untuk para Penyuluh Pertanian Lapangan (PPL) yang bertugas di Wilayah Kerja Penyuluhan Pertanian (WKPP) masingmasing, bertempat di Balai Penyuluhan Pertanian (BPP). Sebagai pelatihnya adalah Penyuluh Pertanian Spesialis (PPS) yang bertugas selain melatih juga menentukan Topic of training untuk para PPL. Topic of trainning berdasarkan "program" dari Penyuluh Pertanian Madya programa. (Penyuluh Pertanian Madya terbagi menjadi dua yaitu Penyuluh Pertanian Madya Programa dan Penyuluh Pertanian Madya supervisor). Program ini berisi rencana kerja PPL yang kemudian diterjemahkan ke dalam topik kunjungan. Seorang Penyuluh Pertanian Madya Programa (programmer) memperoleh data dari para PPL yang berasal dari petani. Penyusunan program berpedoman pada hasil impact point yaitu pokok penentu persoalan yang dilihat dari segi teknis, sosial, dan ekonomi. Latihan ini dilaksanakan secara teratur, satu kali dalam dua minggu dan dilakukan secara berkesinambungan dengan tujuan meningkatkan pengetahuan, kecakapan dan keterampilan para penyuluh, baik teori maupun secara praktek dan selain itu agar dapat memecahkan segala masalah yang ada atau yang timbul di lapangan, melakukan perencanaan untuk dua minggu yang akan datang serta tinjauan pelaksanaan program dua minggu sebelumnya.

b. Kunjungan Kerja, yaitu kunjungan para penyuluh kepada sasaran atau para petani di tempat usaha tani di masing-masing wilayah kelompoknya (wilkel). Dengan dilaksanakannya kunjungan kerja ini diharapkan seorang penyuluh dapat mempengaruhi 20 orang petani dalam setiap wilayah kelompoknya (Kontak Tani beserta 19 orang petani maju). Para anggota setiap kelompok tani (terdiri dari petani maju dan petani maju biasa) diharapkan dapat mempengaruhi 5 orang petani lainnya, dengan demikian bila ada 16 wilayah maka dalam satu wilayah kerjanya para penyuluh dapat mempengaruhi 16 × 20 × 5 kepala keluarga tani $=1.600 \mathrm{KK}$ tani.

Berdasarkan uraian tersebut maka dapat digambarkan sebagai berikut .

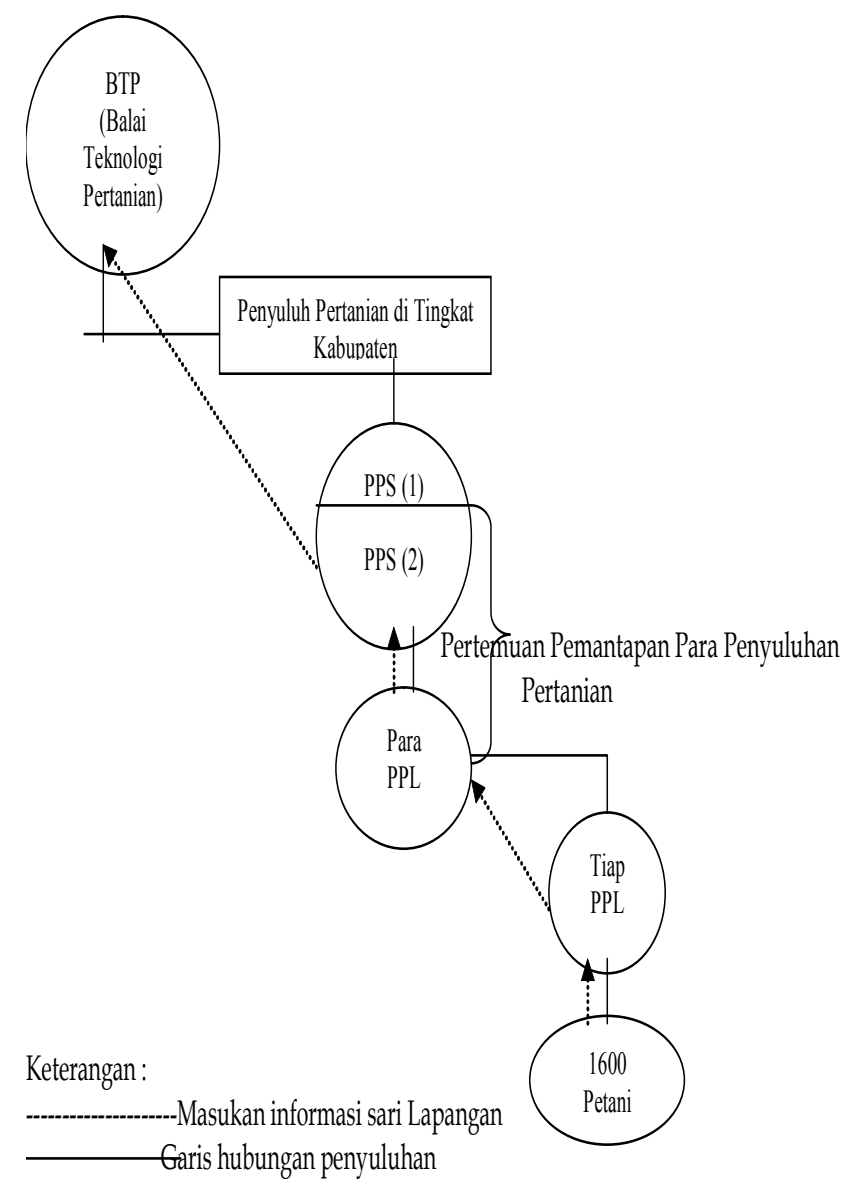

c. Pertemuan antara penyuluh dengan para petani bertempat di dangau pertemuan dan kegiatannya disebut "kegiatan dangau/ kegiatan saung". Dalam pertemuan dangau ini yang memimpin diskusi kelompok adalah kontak tani sedangkan para penyuluh menstimulir kegiatan diskusi itu dan bertindak sebagai resource person.

Jadi dapat dikatakan pula sistem kerja Laku adalah "Kesediaan para petani untuk mengolah usaha tani dan melaksanakan intensitas menuju peningkatan 
produksi pertanian yang nantinya diharapkan meningkatkan juga kesejahteraan dirinya dan keluarga".

Adapun tujuan dari sistem kerja Laku ini adalah mengusahakan adanya hubungan yang berkesinambungan antara para petani dengan sumbersumber teknologi baru yang berkembang dan dapat diterapkan oleh petani dalam kegiatan-kegiatan usaha taninya. Tujuan lainnya adalah memperkecil jurang pemisah antara para petani dengan pihak peneliti pertanian. Masalah yang timbul dapat dengan cepat diterima dan dipecahkan oleh peneliti dan selanjutnya informasi pemecahan masalah tersebut disampaikan lagi kepada petani melalui penyuluhan. Dengan terjalinnya hubungan yang baik antara petani dan peneliti, maka peningkatan produksi dan pendapatan petani dapat tercapai, dan selain itu para peneliti akan lebih efektif dalam menemukan teknologi baru yang sesuai dengan kebutuhan petani.

Kelebihan dari Laku ini adalah sistem kerjanya yang bersifat tetap dan melatih kedisiplinan dari masing-masing pihak serta proses difusi inovasi yang berlangsung cepat dengan berpedoman pada hasil impact point yaitu pokok penentu persoalan yang dilihat dari segi teknis, sosial, dan ekonomi. Sedangkan kelemahan dari sistem kerja Laku ini adalah kelompok tani yang ada sering hanya fiktif, pertemuan sering tidak dilakukan karena jadwal tidak ditepati. Hal ini disebabkan karena letak geografis, pengaruh cuaca, dan lain sebagainya. Disisi lain model kerja Laku ini menerapkan pola pembangunan yang bersifat top down, karena masih berorientasi pada transfer teknologi dari peneliti kepada petani, dimana petani tidak dilibatkan dalam pemecahan masalah mereka sendiri dan hanya menerima informasi hasil penelitian.

\section{Model Penyuluhan SL-PHT}

Sekolah Lapangan Pengendalian Hama Terpadu atau lebih disingkat SL-PHT pertama kali muncul dalam rangka program nasional pengendalian hama terpadu pada tahun 1990 yang dilatarbelakangi oleh ledakan hama wereng coklat. Ledakan hama ini disebabkan oleh adanya penggunaan peptisida secara berlebihan yang mengakibatkan matinya "musuh alami" yaitu hewan yang memangsa hama secara alamiah. Karena musuh alami tidak ada maka meledaklah populasi hama, menyebabkan pemerintah saat itu melarang penggunaan 57 jenis peptisida. Sebagai gantinya pemerintah melakukan pengendalian hama dilakukan secara Pengendalian Hama Terpadu (PHT) dengan slogan "PHT bukan untuk petani, tetapi PHT oleh petani", "Peptisida bukannya obat tetapi racun”.
PHT adalah pengendalian hama yang berbasis biologis dan akrab dengan lingkungan, yang dilaksanakan melalui perpaduan tiga cara yaitu pengedalian hama melalui musuh alami (yang terdiri dari predator, parasit, dan patogen), pengendalian hama dengan menggunakan tanaman yang resisten, dan pengendalian hama dengan menerapkan manajemen penanaman. Keuntungan PHT menyangkut empat aspek, yaitu sebagai berikut.

a. Aspek stabilitas produksi pangan (swasembada pangan).

b. Aspek ekonomis (meningkatkan pendapatan dan kesejahteraan petani dan anggotanya serta penghematan pengeluaran pemerintah sebesar 50 - 100 juta US dolar per tahun).

c. Aspek kesehatan (terhindar dari timbulnya penyakit kanker, kejang-kejang, gangguan syaraf, lumpuh, dan kelainan bayi yang cacat).

d. Aspek lingkungan (misal matinya belut, ikan, berudu dan binatang yang berguna lainnya).

Untuk mendukung PHT tersebut, pada fase awal perlu diadakan pelatihan bagi petugas. Setelah itu petugas yang telah dilatih tersebut akan melakukan penyuluhan kepada para petani melalui kegiatan SLPHT. Selanjutnya SL-PHT dilakukan oleh petani pemandu, artinya petani melakukan PHT kepada petani lainnya. SL-PHT merupakan suatu "sekolah tanpa dinding" sehingga ruang kelas sekaligus ruang perpustakaan adalah lahan sawah itu sendiri. Peserta SL-PHT berkumpul satu kali seminggu selama satu musim (12 minggu atau $12 \times$ pertemuan) untuk mengikuti dan menganalisis perkembangan tanaman mereka, fase demi fase. Selain itu mereka mendalami berbagai prinsip yang terkait dengan perkembangan seperti dinamika populasi serangga, fisiologi dan kompensasi tanaman, pemeliharaan kesuburan tanah, pengaruh air dan cuaca, pemilihan varietas, dan lainlain melalui eksperimen-eksperimen yang mereka lakukan sendiri. Selain kegiatan pokok, serangkaian kegiatan (topik khusus) dilakukan sesuai dengan masalah-masalah khusus yang dihadapi di setiap tempat. Yang selalu nampak pada SL-PHT adalah peran aktif petani sebagai pelaku, peneliti, pemandu, dan manajer lahan yang ahli.

Adapun proses sosialisasi dari SL-PHT ini yaitu sebagai berikut.

a. Pertemuan di tingkat kecamatan yaitu antara aparat dengan Pengamat Hama Penyakit (PHP) dan penyuluh, bertujuan untuk menentukan daerah/desa mana yang akan diadakan SLPHT. 
b. Pertemuan di tingkat desa yang dilakukan oleh aparat kecamatan yang tujuannya untuk menentukan hamparan mana yang akan diadakan SL-PHT.

c. Pertemuan tingkat hamparan dengan mengundang seluruh petani dilokasi hamparan, tujuanya sebagai berikut.

1) Menentukan peserta SL, dengan membuat matriks kontribusi peran antar petani laki dan petani wanita, misalnya 20 orang petani laki dan 5 orang petani wanita $=25$ peserta.

2) Menentukan topik, dengan membuat peta hamparan. Dari peta hamparan dirumuskan melakukan untuk 12 kali pertemuan dimana topik tiap pertemuan ditentukan oleh petani.

3) Kontrak pelajar, yaitu rencana belajar yang disepakati oleh petani antara lain; penentuan lokasi belajar, penentuan jadwal, pembagian uang saku, dan sangsi bagi yang tidak hadir.

4) Evaluasi, ditentukan petani sendiri apakah berhasil atau tidak pelaksanaan SL-PHT ini. Seperti yang telah diuraikan bahwa SL-PHT ini terdiri dari 12 kali pertemuan dimana satu kali pertemuan mempunyai jadwal, yaitu sebagai berikut.

a) Jam 7.00 - 8.00 Petani melakukan pengamatan pada hamparaan dengan perbandingan antara yang dibuat oleh PHP dan lokal (milik petani).

b) Jam 8.00 - 9.00 Petani melakukan diskusi kelompok dari hasil pengamatan yang kemudian dituangkan dalam gambar.

c) 9.00 - 10.00 Petani melakukan persentasi (petani mendapatkan ilmu) dan disimpulkan kemudian diambil tindakan.

d) Jam 10.00 - 11.00 Petani istirahat.

e) Jam 11.00 - 12.00 Petani melakukan tinjauan khusus.

Selama proses pertemuan penyuluh lebih banyak bertindak sebagai pemandu, artinya petani yang lebih banyak memiliki peran.

Prinsip-prinsip dalam kegiatan SL-PHT ini adalah petani sebagai ahli, dalam arti petani dianggap sebagai subjek bukan objek pembangunan. Sebagai program pengembangan sumber daya manusia, pelatihan ini membantu petani menguasai konsep berpikir yang baru dan menerapkan cara-cara baru untuk memecahkan masalah yang dihadapi. Prinsip lain adalah bersifat berkelanjutan, yaitu menekankan keberlanjutan pada hubungan petani dengan sumberdaya alam yang ada dan kemampuan petani untuk menerapkan cara-cara PHT dilahannya sendiri sehingga petani adalah pemilik utama dan pelaksana PHT. PHT merupakan suatu pendekatan ekologi, yaitu memandang sistem pertanian sebagai suatu sistem kompleks yang "hidup", tempat manusia berinteraksi dengan tanah, tanaman, dan organisme hidup lainnya, dalam rangka mengoptimumkan sumberdaya yang ada. Dari sudut pandang ini petani belajar bekerjasama dengan alam, bukan mencoba menguasainya atau menyalahgunakan lingkungan hidup disekitarnya.

Pola dasar SL-PHT dirancang sedemikian rupa untuk dapat mengakomodir semua karakteristik petani sebagai orang dewasa yang menjadi faktor penentu keberhasilan bagi proses penyuluhan. SL-PHT dirancang agar petani sebagai orang dewasa memiliki kesempatan yang seluas-luasnya untuk belajar dengan cara berinteraksi dengan realita secara langsung, kemudian menemukan sendiri ilmu dan prinsip atau kaidah yang terkandung di dalamnya yang dapat diaplikasikan dalam kegiatan mengelola usaha taninya. Dengan demikian pola pembelajaran SL-PHT bukan hanya sekedar learning by doing, melainkan suatu proses dimana semua warga belajar yang semuanya orang dewasa ini dapat menemukan ilmu (discovery learning) yang dinamis melalui pengalaman, pengungkapan pengalaman (processing) dan menarik kesimpulan serta menerapkannya dalam manajemen usaha taninya masing-masing, sesuai dengan situasi kehidupan sehari-hari yang saling berbeda. Pola ini sering disebut CBLP (Cara Belajar Lewat Pengalaman), yaitu salah satu metode pembelajaran orang dewasa.

Jika dicermati model SL-PHT ini lebih bersifat bottom up yang tercermin dalam setiap pertemuannya. Terlepas dari itu semua, terdapat kelemahan dalam sistem SL-PHT ini yaitu pelaksanaannya yang lambat dan lebih membutuhkan biaya yang besar karena satu desa hanya ada 1-2 SL.

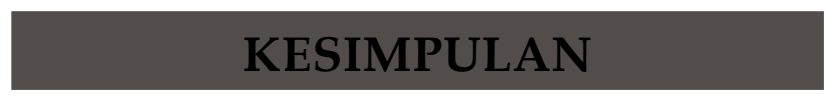

Sebagai penutup dari tulisan ini maka dapat disimpulkan bahwa penyuluhan pembangunan bertujuan menghasilkan manusia berkualitas melalui proses penyadaran diri. Proses penyadaran diri dari orang banyak memerlukan suatu ilmu tersendiri yaitu ilmu penyuluhan. Pelaksanaannya perlu ditangani oleh individu-individu yang khusus dilatih untuk melakukan penyuluhan. Karena itu pendidikan di bidang penyuluhan yang ditangani secara serius akan membantu mewujudkan tenaga-tenaga penyuluh yang profesional. Penyuluhan pertanian sebagai cikal bakal penyuluhan pembangunan turut pula memberikan andil dalam pembangunan masyarakat terbukti 
dengan adanya program-progam yang berorientasi pada peningkatan kualitas diri, terlepas dari segala kelebihan dan kelemahannya.

\section{DAFTAR PUSTAKA}

Depatemen Pertanian. (1995). Modul SL-PHT, Yogyakarta.

Kartasapoetra, A.G. (1994) Teknologi penyuluhan pertanian. Jakarta: Bumi Aksara.

Lunandi, A.G(1984). Pendidikan orang dewasa sebuah uraian praktis untuk pembimbing, penatar, pelatih, dan penyuluh lapangan. Jakarta: Gramedia.

Mangkuprawira, Sjafri. (2000). Makalah pelatihan manajemen dan metodologi penyuluhan bagi peneliti.

Mardikanto, Totok. (1993). Penyuluhan pembangunan pertanian.Solo: Sebelas Maret University Press
Slamet, Margono. (2000). Memantapkan posisi dan meningkatkan peran penyuluhan pembangunan dalam pembangunan. Dalam proseding seminar IPB Bogor: Pemberdayaan sumberdaya manusia menuju terwujudnya masyarakat madani. Pustaka Wira Usaha Muda.

Soediyanto. (1997). Makalah tentang SL-PHT tanggal 2 Desember 1997. Univesitas Brawijaya Malang.

Van Den Ban,A.W. (1999). Penyuluhan pertanian.

\section{KETERANGAN PENULIS}

Puji Hardiyanti, M.Si., dilahirkan di Jakarta, Oktober 1974. Saat ini aktif sebagai dosen Universitas Negeri Jakarta. Salah satu artikel ilmiah yang dihasilkan adalah Esensi Penyuluhan dalam Pendidikan Luar Sekolah. 